\title{
Petrographic and geochemical study of organic matter in surficial laminated sediments from an upwelling system (Mejillones del Sur Bay, Northern Chile)
}

\author{
J. Valdés ${ }^{\text {a, b }}$, A. Sifeddine $e^{b}$ E. Lallier-Verges ${ }^{c}$ and L. Ortlieb $^{b}$

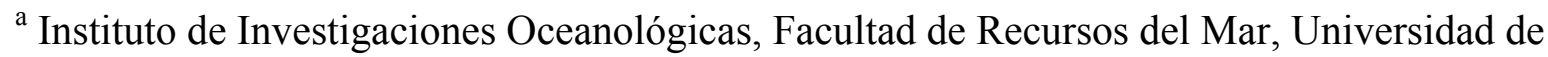 \\ Antofagasta, Av. Universidad de Antofagasta s/n, Antofagasta, Chile \\ ${ }^{\mathrm{b}}$ IRD, Programme PALEOTROPIQUE, Centre de Recherche Ile de France, Bondy, France \\ ${ }^{\mathrm{c}}$ Institut des Sciences de la Terre d'Orléans. UMR 6113 CNRS/Université d' Orléans, 1A rue \\ de la Férollerie F-47072, Orléans Cedex 2, France
}

\section{Abstract}

A study of recent laminated sediments, accumulated in the oxygen minimum zone of Mejillones Bay (Northern Chile), shows that the organic matter is autochthonous and deposited under varying oceanographic conditions. Sedimentary units dominated by light laminations have low values of total organic carbon, total nitrogen and sulphur, and Chaotoceros content, coupled with high values of yellow amorphous organic matter. These were deposited under conditions of low primary productivity, favoring the recycling of the major part of metabolizable organic matter in the water column, and the accumulation only of non-metabolizable organic matter in the bottom sediments. In contrast, a unit rich in dark laminations with high values of total organic carbon, total nitrogen and sulphur, shows high values of brown and black AOM, and Chaetoceros content. This sedimentary unit reflects increased flocculation of organic particles during a period of high productivity and fast transit of organic material through the column water, thus diminishing the recycling of metabolizable organic matter and its accumulation with non-metabolizable organic matter in the sediments. Finally, a unit characterized by presence of both light and dark laminations was formed by abrupt alternations of the two oceanographic states described previously.

\section{Introduction}

Coastal upwelling systems have strong impacts on marine and atmospheric biogeochemical cycles (Thunell et al., 1992; Martinez et al., 1999). The enhanced biological productivity observed close to these upwelling cells in Eastern boundary systems induces an increased flux of organic material to the coastal ocean floor, producing characteristic changes in the water column and bottom sediments. Significant effects are generated, for example, on the global cycles of carbon ( Ransom et al., 1998; Hulthe et al., 1998; Lükge et al., 1999), and nitrogen ( Hulth et al., 1999). The concentration of oxygen in the water column in these environments declines markedly with depth, a condition that limits the degradation processes and favors the preservation of biogenic remains. Thus, in this kind of environment the organic carbon content of sediments may reach 10\% ( Libes, 1992; Hedges and Keil, 1995) while mean oceanic values vary between $0.2 \%$ and $0.4 \%$ ( Müller and Suess, 1979; Duan, 2000).

The preservation of organic matter in marine sediments is principally controlled by the supply of biomass originating in the euphotic zone and by degradation processes which occur in the photic zone, throughout the water column and in the sediments (Murria and Kuivila, 1990; Lallier-Vergès et al., 1991; Lallier-Vergès et al., 1993; Bertrand et al., 1993; Tribovillard et 
al., 1994; Ransom et al., 1998; Ganeshram et al., 1999; Duan, 2000). The redox conditions of the depositional environment reflect the intrinsic characteristics of the water mass, and the oxygen consumption driven by the microbial degradation of organic matter. Various studies ( Hedges and Keil, 1995; Thamdrup and Canfield, 1996; Boussafir and Lallier-Vergès, 1997; Lallier-Vergès et al., 1998; Cowie et al., 1999; Vetö et al., 2000) have shown that there is a series of factors involved in the control of organic matter content in marine sediments, such as its flux in the water column, the sedimentation rate, the oxygenation of bottom waters, the water-depth and the distance from the coast. Although synergism among these factors may be assumed, there is no consensus as to which factors control this mechanism. Authors such as Reimers (1989), Pedersen and Calvert (1990) and Calvert et al., 1992 and Calvert et al., 1996 propose that productivity has a major influence, whereas others such as Didyk et al. (1978), Hollander et al. (1992), Ingall and Jahnke (1994), Jones and Manning (1994) and Schulte et al. (2000) suggest that the availability of oxygen is the principal factor regulating the preservation of organic matter in sediments.

Marine sediments accumulated near upwelling cells provide valuable information regarding the evolution of local oceanographic conditions (Martinez et al., 2000; Bertrand et al., 2003). In favorable circumstances, such sediments may record former physico-chemical characteristics of the water column with a high time resolution. Depending upon the sedimentation rate and the biological processes involved locally, the sedimentary sequences may thus provide relevant records of seasonal to interannual, to interdecadal, variability of ocean-atmosphere interactions.

The Punta Angamos upwelling system $\left(23^{\circ} \mathrm{S}\right)$ is known as one of the most productive marine regions off the Chilean coast, and has been the object of various studies in recent years (Escribano, 1998; Gonzalez et al., 1998 and Gonzalez et al., 2000; Marín and Olivares, 1999; Escribano and Hidalgo, 2000; Thomas et al., 2001). Mejillones del Sur Bay, which forms part of this system ( Fig. 1), acts as a center of sedimentary deposition for the abundant biological productivity of the zone (Valdés, 1998; Vargas, 1998). This bay is located off the world's driest desert (Atacama), and thus material of continental origin which reaches coastal sediments in the area is limited solely to wind-transported particles ( Vargas, 1998). Primary productivity measurements in this bay have given average annual production of $1070 \mathrm{~g} \mathrm{C} \mathrm{m}^{-2}$ $\mathrm{y}^{-1}$ (Marín et al., 1993), while dissolved oxygen profiles measured over an annual cycle showed that, at depths greater than 50 meters, oxygen is depleted (Valdés, 1998; Escribano, 1998), which strongly restricts the presence of benthic macrofauna ( Zúñiga, 1974; Zúñiga et al., 1983). These factors have favored the rapid accumulation of diatomaceous organic-rich sediments, in which there is very little bioturbation. For example, chemical analyses of various cores showed mean diatom opal and organic carbon contents of $49 \%$ and $8 \%$, respectively ( Valdés, 1998; Vargas, 2002), and sedimentations rates of $131 \pm 7 \mathrm{~cm} \mathrm{ky}^{-1}$ (Vargas, 2002). These characteristics are ideal for the reconstruction of local paleoceanographic conditions at the scale of the last centuries and millennia ( Ortlieb et al., 1994 and Ortlieb et al., 2000; Valdés, 1998; Vargas, 2002; Valdés et al., 2000; Valdés and Ortlieb, 2001; Valdés et al., 2003). 


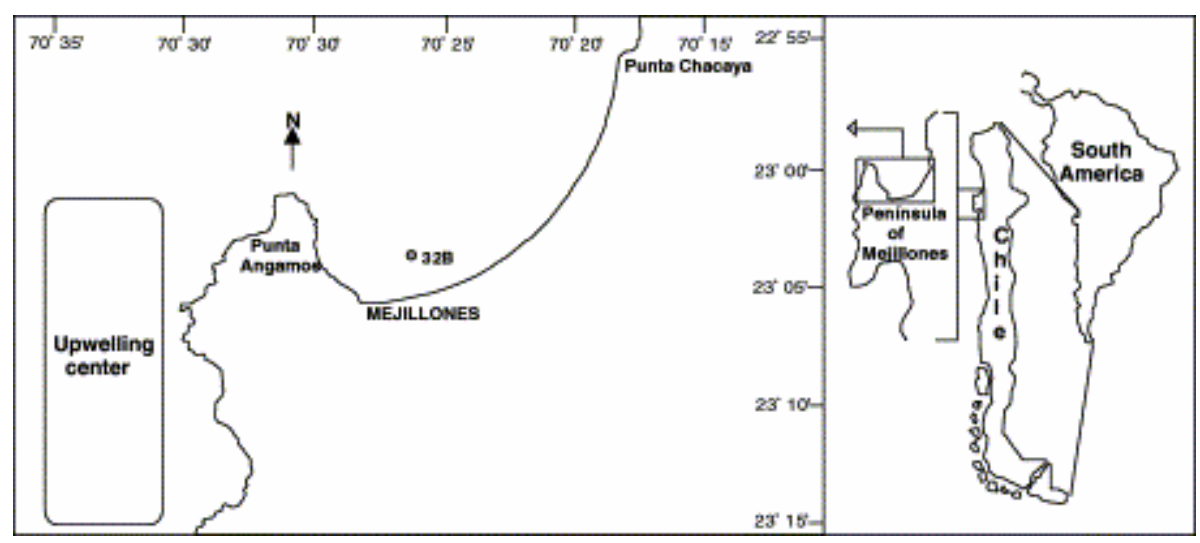

Fig. 1. Location of Mejillones Bay on the west coast of South America, close to the upwelling center of Punta Angamos, and of core 32B.

Reconstruction of the environmental changes over the past thousand years in Mejillones Bay requires an understanding of the factors that control marine sedimentation in the area. The biogenic nature of the sediments accumulated within the bay implies that such a study must be focused on the variation through time of the accumulation and preservation processes. One of the promising approaches to decipher the combinations and variation of the different interacting factors in these processes is to assess changes in the organic matter deposited in the sediments over time. The present study reports on high-resolution geochemical and petrographic work carried out on the organic fraction of sediments recovered from a core obtained in Mejillones Bay. Results were used to reconstruct paleoenvironmental conditions both within the water column and in the interface sediments, at the time of their deposition.

\section{Materials and methods}

Samples for geochemical and petrographic analyses were recovered from a $44 \mathrm{~cm}$ long sediment core, collected in the central area of Mejillones Bay (Fig. 1). The core was subsampled according to presence of dark and light laminations observed in a radioscopic image.

\subsection{Geochemistry}

The samples were analyzed using Rock-Eval 6 programmed pyrolysis (Lafargue et al., 1998), from which the following parameters were obtained: total organic carbon (TOC), hydrogen index (HI), expressed as $\mathrm{mg} \mathrm{HC} / \mathrm{g}$ TOC, and oxygen index (OI) expressed as $\mathrm{mg} \mathrm{CO}_{2} / \mathrm{g}$ TOC. An induction furnace (LECO,) was used to quantify the total sulfur (TS), total nitrogen (TN) and total carbon (TC) contents.

\subsection{Petrography}

Observations on dried sediment smear slides were made for comparison with palynofacies preparations. In these preparations, Chaetoceros abundance was estimated according Pichon (1985), and results were expressed in $\mathrm{N}^{\circ} \mathrm{cm}^{-2}$.

The petrographic study was carried out on kerogen fraction, isolated from the carbonate and silicate phases of the sediment via the classical hydrochloric and hydrofluoric acid treatments (Durand and Nicaise, 1980). This study involved the identification and relative quantification 
of the different fractions of organic matter using transmitted light microscopy (palynofacies). Estimation of the relative abundance of these different fractions was carried out by means of charts routinely used in organic petrology and based on surface particle quantification, in 30 microscopic fields ( Sifeddine and Bertrand, 1994; Sifeddine et al., 1996). Observations with reflected light were also made on polished sections of 17 samples in order to estimate framboidal pyrite abundance. Results were expressed in percentage of total abundance. Scanning Electron Microscopy (SEM) observations were carried out in selected samples. Fourier Transform Infrared (FTIR) spectra of different types of organic matter (in a minimum of 4 of each type) identified in transmitted light were obtained scanning from 400 to 4000 $\mathrm{cm}^{-1}$ (Rochdi et al., 1991).

\section{Results and discussion}

\subsection{Structure and organic composition of Mejillones bottom sediments}

Visual observations and X-ray radioscopic images (Fig. 2) indicate that core 32B does not contain any abrupt sedimentological changes, such as deposition of turbidities or hiatus in sedimentation. Instead, light and dark laminations dominate throughout the length of the core, which permit the identification of three sedimentary units:

- Unit A: corresponds to the lower part of the core (44 to $36 \mathrm{~cm}$ ) and shows a predominance of light laminations.

- Unit B: corresponds to the middle section of the core (between 36 and $12 \mathrm{~cm}$ ) and presents an alternation of light and dark laminations, with thickness varying between 1 and $10 \mathrm{~mm}$.

- Unit $\mathrm{C}$ : corresponds to the upper part of the core $(12$ to $0 \mathrm{~cm})$ and is characterized by a predominance of dark laminations

Table 1 shows the mean and standard deviation for all parameters measured in core 32B separated by each stratigraphic unit. Except for OI, all others parameters present notable differences in mean values between these three units. In order to evaluate if these differences are due to artefacts (i.e., sampling technique or analyses procedures) a one-way ANOVA test was applied (Table 2); only OI does not present a probability ( $p$ value) less than 0.001 (significant level). Thus, the geochemical and petrographic composition of units may be interpreted as a record of different sedimentary processes. 


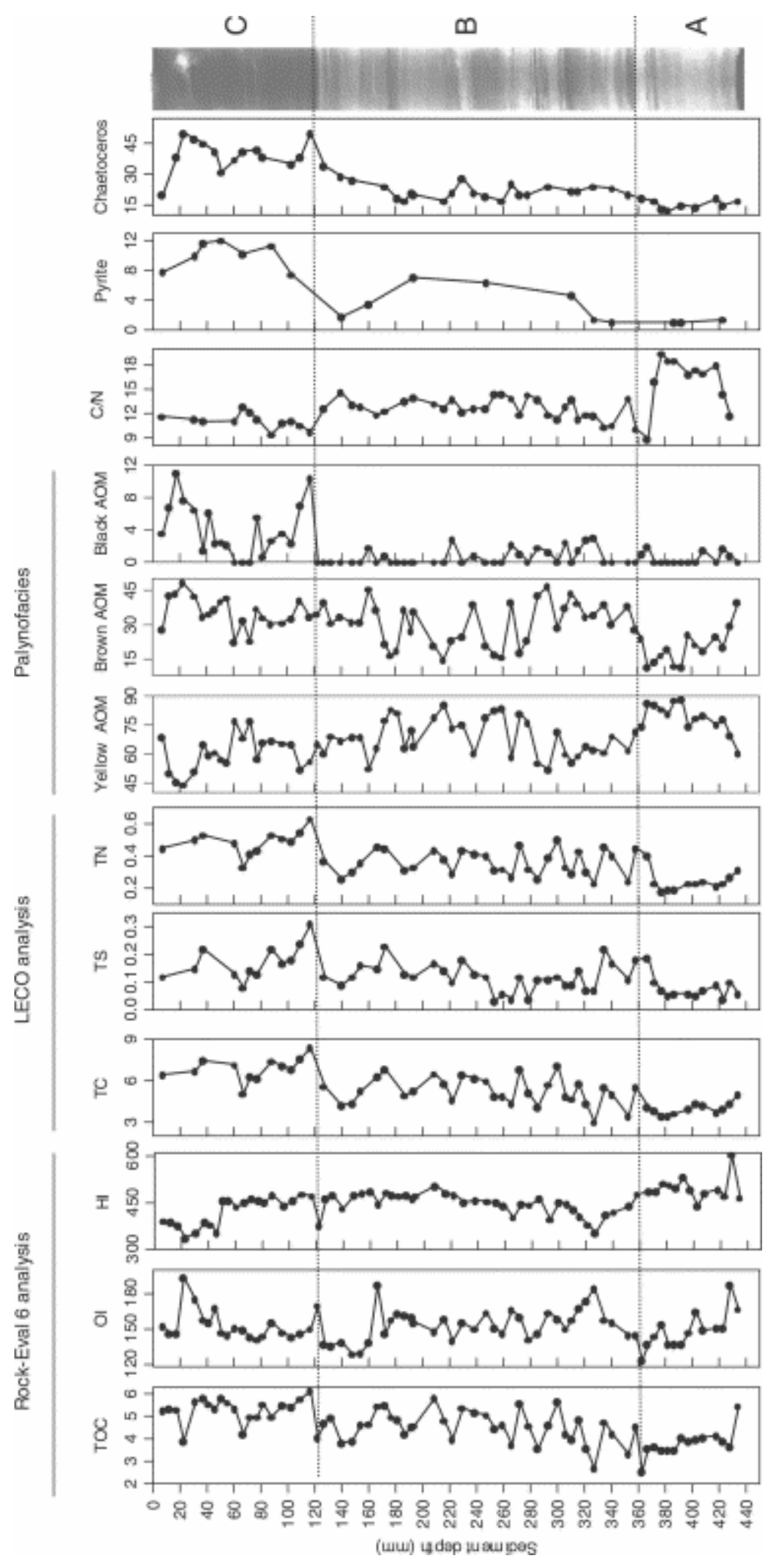

Fig. 2. Radioscopic image, geochemical and petrographic profiles of Core 32B. Stratigraphic units are indicated. OI is expressed in milligrams $\mathrm{CO}_{2} / \mathrm{g}$ TOC. HI is expressed in $\mathrm{mg} \mathrm{HC} / \mathrm{g}$ TOC. TOC, TC, Ts and TN, are expressed in \% of bulk sediment. Organic fraction (palynofacies) is expressed in relative abundance (\%). Chaetoceros is expressed in $\mathrm{N}^{\circ} \mathrm{cm}^{-2}$. Framboidal pyrite is expressed in relative abundance (\%). 
Table 1. Geochemical parameters of sediments analyzed from core 32B taken from the center of Mejillones Bay, Chile

\begin{tabular}{|c|c|c|c|c|}
\hline \multirow[t]{2}{*}{ Parameter } & & \multicolumn{3}{|c|}{ Core section } \\
\hline & & $\mathrm{C}$ & B & $\mathrm{A}$ \\
\hline \multirow[t]{2}{*}{ TOC } & Mean & 5.3 & 4.5 & 3.8 \\
\hline & SD & 0.5 & 0.7 & 0.6 \\
\hline \multirow[t]{2}{*}{ HI } & Mean & 424 & 448 & 517 \\
\hline & SD & 46.5 & 34.3 & 78 \\
\hline \multirow[t]{2}{*}{$\mathrm{OI}$} & Mean & 153 & 154 & 149 \\
\hline & SD & 12.9 & 13.3 & 16.2 \\
\hline \multirow[t]{2}{*}{$\mathrm{TC}$} & Mean & 6.9 & 5.3 & 4.0 \\
\hline & SD & 0.8 & 1.0 & 0.5 \\
\hline \multirow[t]{2}{*}{ TS } & Mean & 0.17 & 0.12 & 0.07 \\
\hline & SD & 0.06 & 0.05 & 0.04 \\
\hline \multirow[t]{2}{*}{ TN } & Mean & 0.5 & 0.4 & 0.2 \\
\hline & SD & 0.1 & 0.1 & 0.1 \\
\hline \multirow{2}{*}{$\begin{array}{c}\text { YELLOW } \\
\text { AOM }\end{array}$} & Mean & 60.5 & 68.5 & 78.7 \\
\hline & SD & 9.3 & 9.5 & 7.8 \\
\hline \multirow{2}{*}{$\begin{array}{c}\text { BROWN } \\
\text { AOM }\end{array}$} & Mean & 35.4 & 30.8 & 20.7 \\
\hline & SD & 6.8 & 9.1 & 7.8 \\
\hline \multirow{2}{*}{$\begin{array}{r}\text { BLACK } \\
\text { AOM }\end{array}$} & Mean & 4.1 & 0.6 & 0.5 \\
\hline & SD & 3.4 & 1.0 & 0.7 \\
\hline \multirow[t]{2}{*}{$\mathrm{C} / \mathrm{N}$} & Mean & 11.1 & 12.7 & 16.1 \\
\hline & SD & 0.9 & 1.2 & 3.2 \\
\hline \multirow[t]{2}{*}{ Chaetoc. } & Mean & 31 & 19 & 15 \\
\hline & SD & 10.2 & 4.0 & 1.9 \\
\hline
\end{tabular}

Its showed mean and standard deviation values by each stratigraphic unit recognized in core 32B.

Table 2. Results of one-way ANOVA analyses performed on geochemical and petrographic results of core 32B

\begin{tabular}{cccccccccccc}
\hline & TOC & HI & OI & TC & TS & TN & YEAOM & BRAOM & BLAOM & C/N & Chaet \\
\hline$F$ & 23.54 & 15.45 & 0.59 & 31.04 & 10.49 & 30.54 & 16.61 & 13.2 & 24.18 & 24.27 & 27.41 \\
$p$ & 0.000 & 0.000 & 0.556 & 0.000 & 0.000 & 0.000 & 0.000 & 0.000 & 0.000 & 0.000 & 0.000 \\
\hline
\end{tabular}

The variations of geochemical and petrographical parameters confirm the presence of the three lithological units. The general profile for TOC, TC, TS, and TN shows a slight increase towards the sediment surface, whereas HI profile shows an opposite trend (Fig. 2). Profiles are in agreement with stratigraphic units as revealed by radioscopic analyses. Unit A with a predominance of light laminations showed low mean values of TOC $(3.8 \%)$, TN $(0.2 \%)$, TS (0.07\%), OI (149 $\mathrm{mg} \mathrm{CO} / \mathrm{g}$ TOC) and high $\mathrm{C} / \mathrm{N}$ (16.1) ratio and $\mathrm{HI}(517 \mathrm{mg} \mathrm{HC} / \mathrm{g}$ TOC), 
while unit $\mathrm{C}$, with predominance of dark laminations has high mean values of TOC $(5.3 \%)$, TN (0.5\%), TS (0.17\%), OI (153 $\mathrm{mg} \mathrm{CO}_{2} / \mathrm{g}$ TOC) and lower mean values of $\mathrm{C} / \mathrm{N}(11.1)$ ratio and $\mathrm{HI}$ (424 mg HC/g TOC) (Table 1). The unit B, characterized by alternate dark and light laminations, represents an intermediate situation between units $\mathrm{A}$ and $\mathrm{C}$.

Palynofacies showed that the OM accumulated in Mejillones Bay is composed only of Amorphous Organic Matter (AOM). According to color properties (Durand, 1980), it is possible to distinguish and quantify three different types of amorphous organic matter yellow, brown, and black - whose proportions are given in Fig. 2.

This approach shows that unit $\mathrm{C}$ is marked by high content of brown (35\%) and black (4\%) AOM, while the unit A is characterized by a predominance of yellow AOM (79\%). SEM revealed that there are differences in structures of AOM related to palynofacies color classification. In fact, color corresponds to the degree of agglomeration presented by AOM. These differences were more marked between yellow and the other two color fractions (brown and black) which had more or less the same structure. This situation permitted the classification of the AOM in two categories; light AOM, composed of large massive homogeneous areas of organic matter with a dispersed texture, corresponding to yellow AOM; dark AOM, composed of less homogeneous regions of organic matter with a speckled aspect (more or less granular), corresponding to brown and black AOM (Fig. 3). The representative FTIR spectra obtained from light and dark AOM showed the same functional groups (Fig. 4). Some differences can be seen between the intensities of the absorption band, that is higher for dark AOM. Both spectra are characterized by the presence of simple monoaromatic compounds and alkanes $\left(\mathrm{CH}_{3}, \mathrm{CH}_{2}\right)$, plus alcohol and phenol functional groups. 
।
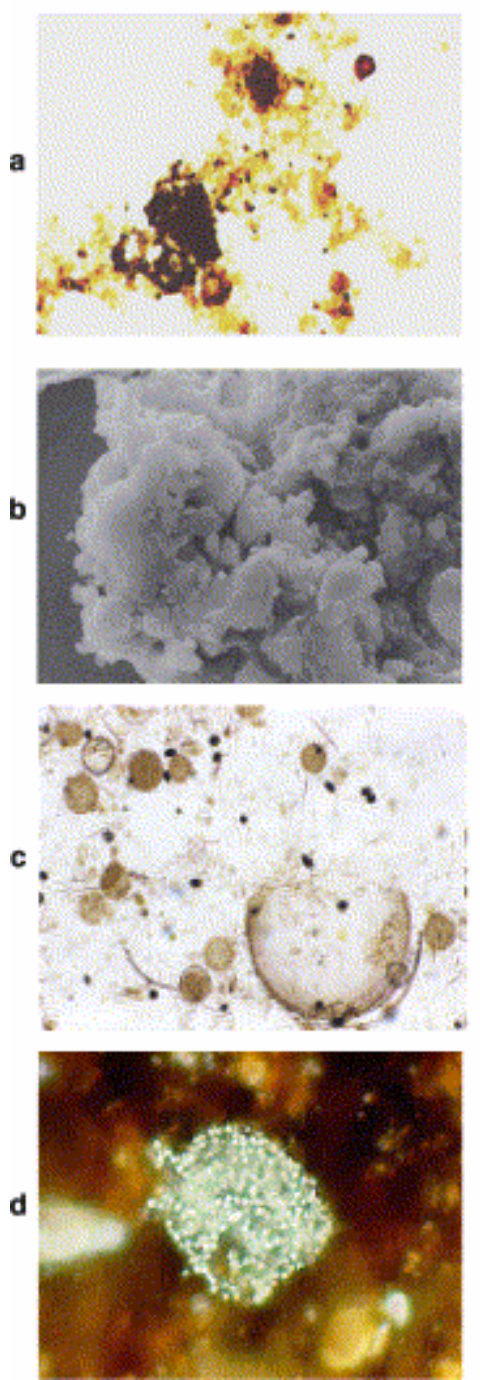

॥
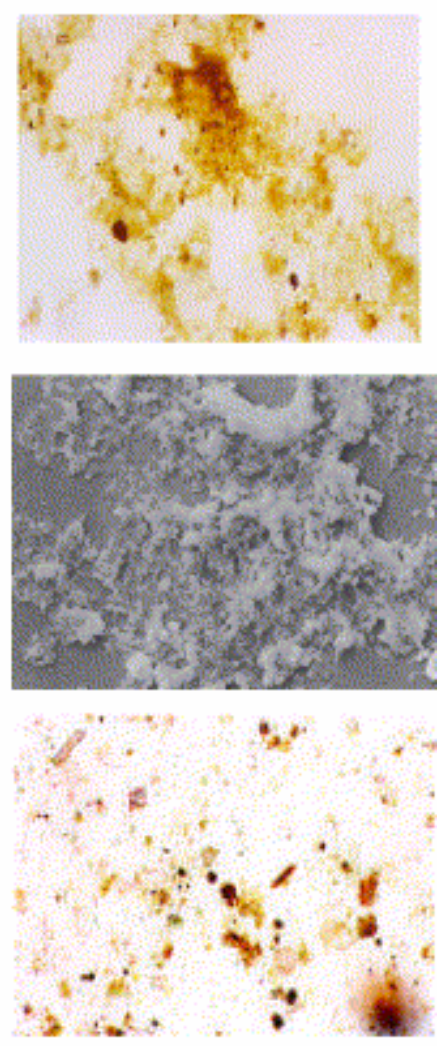

Fig. 3. Results of the optical technique study: (a) AOM under transmitted light; (b) SEM; (c) smear slide under transmitted light; (d) a polished section under reflected light. Column I corresponds to a sedimentary record of high agglomerated AOM content, and column II to a sedimentary record of low content of agglomerated AOM content. 

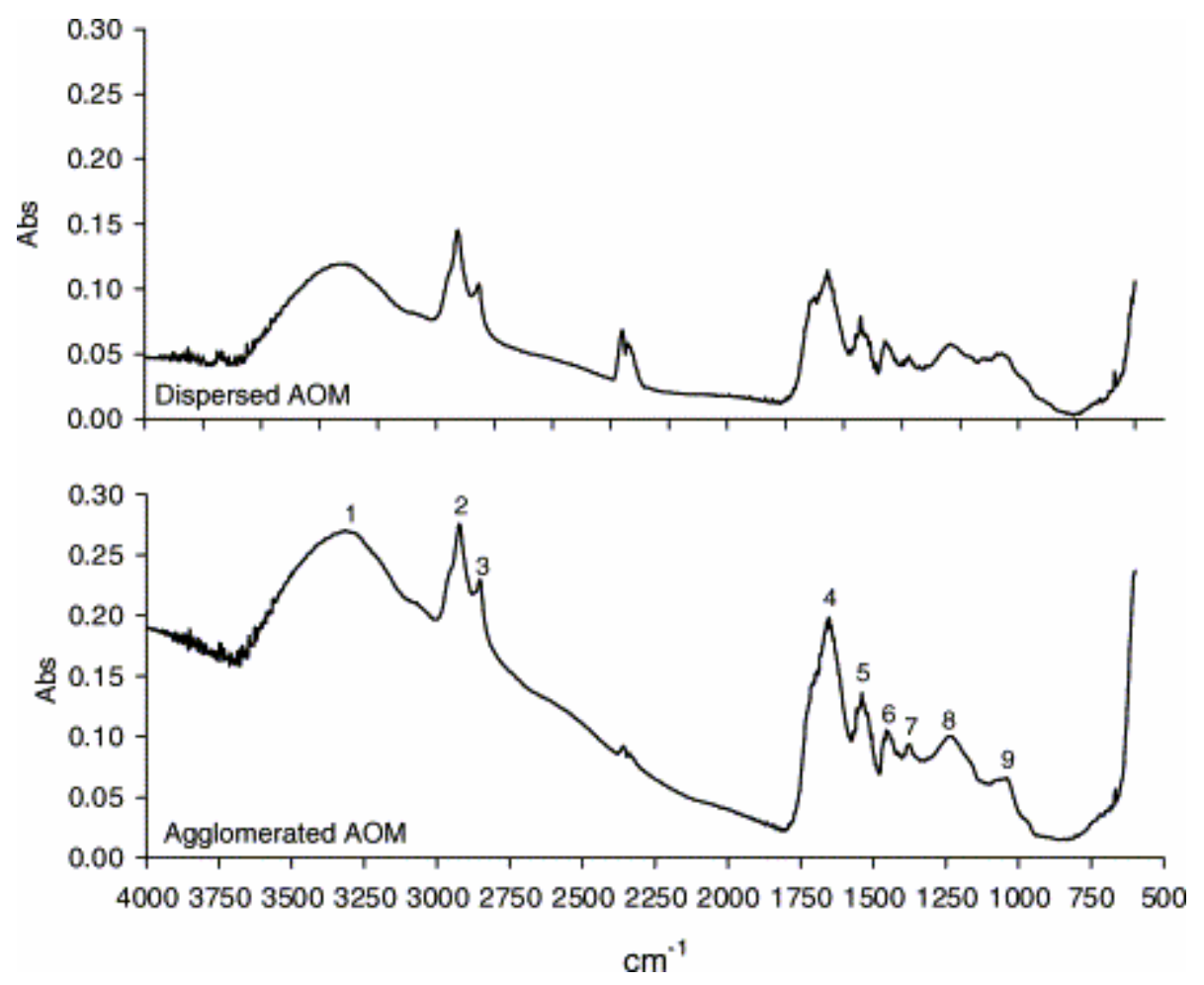

Fig. 4. FTIR (Fourier Transform Infrared) spectra of both AOM types identified in 32B core. The upper picture corresponds to the dispersed (light) AOM, and the lower one shows the agglomerated (dark) AOM. FTIR analyses of both types of organic matter identified in core 32B: (1) ${ }^{-} \mathrm{OH}$ of alcohol or phenols; (2) $\mathrm{CH}_{3}$ aliphatic alkanes; (3) $\mathrm{CH}_{2}$ aliphatic-alkanes; (4) $\mathrm{C}=\mathrm{C}$ of aromatic hydrocarbons; (5) $\mathrm{C}-\mathrm{H}$ of aromatic hydrocarbons; (6) ${ }^{-} \mathrm{OH}$ of alcohols or phenols; (7) $\mathrm{CH}_{3}$ of aliphatic hydrocarbons; (8) $\mathrm{C}-\mathrm{H}$ of aromatic hydrocarbons; (9) ${ }^{-} \mathrm{OH}$ of alcohols or phenols.

\subsection{Origin of organic matter}

Geochemical and organic petrographic analyses reveal that the organic matter accumulated in Mejillones Bay is of marine origin. The results of Rock-Eval 6 pyrolysis, plotted on the pseudo Van Krevelen diagram (Tissot and Welte, 1984) indicate that the organic matter is of Type II (phytoplanktonic origin) ( Fig. 5), and is immature, according to Tmax values ranging between 394 and $441{ }^{\circ} \mathrm{C}$ (mean $=421{ }^{\circ} \mathrm{C}$ ). The whole sequence of core $32 \mathrm{~B}$, based on palynofacies analysis, contains amorphous organic matter (AOM) formed of agglomerates without definite shapes linked to phytoplankton production (Lallier-Vergès et al., 1998). The palynofacies analysis do not show organic material derived from terrigenous OM. 


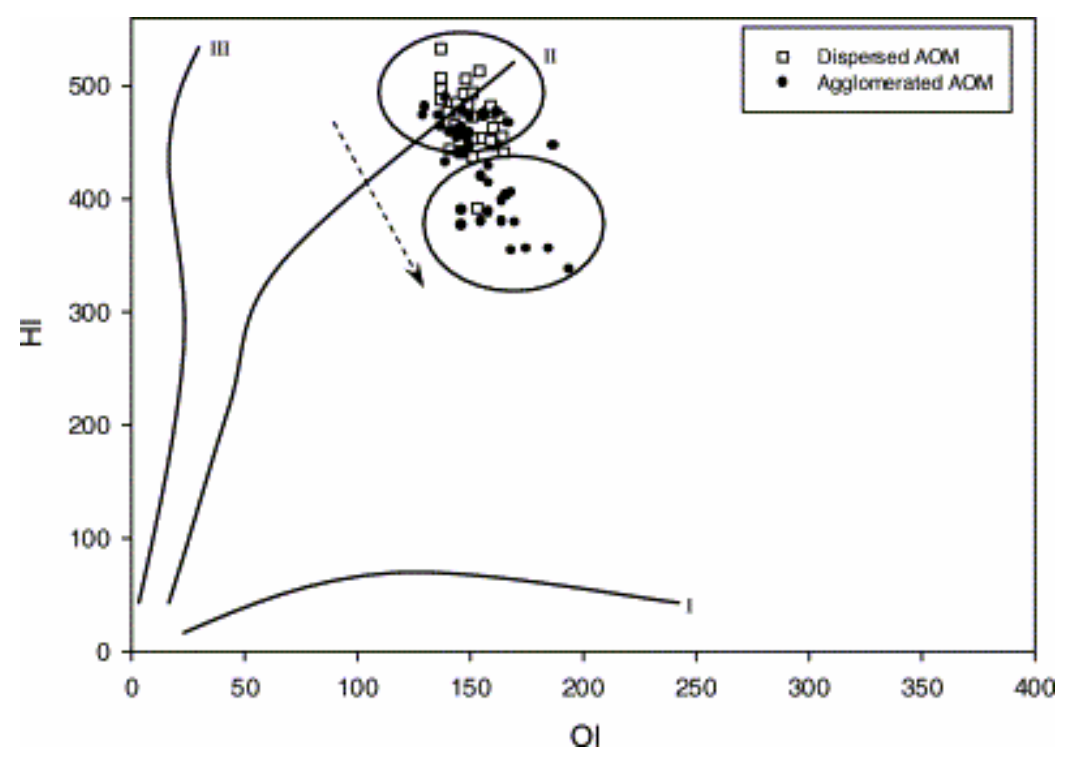

Fig. 5. HI vs. OI for core 32B. Filled circles correspond to agglomerated material, rich in metabolizable AOM. White squares correspond to dispersed material, with prevailing, non-metabolizable AOM. Oxidation route between dispersed and agglomerated AOM (Meyers and Lallier-Vergès, 1999) is shown.

Observations of total sediment smear slides reveal that the agglomerated AOM, corresponds to flakes deposited during periods of high productivity (Lallier-Vergès et al., 1998). Predominately in the unit $\mathrm{C}$, this $\mathrm{AOM}$ is associated with abundant remains of siliceous phytoplankton, mainly Chaetoceros and diatoms such as Coscinodiscus and Thalassiosira, which are indicators of intense upwelling (Sauter and Sancetta, 1992; Bull and Kemp, 1995), especially in Mejillones Bay ( Rodríguez and Escribano, 1996) ( Fig. 3c), which explains the high values of TOC. Conversely, unit A which is enriched in dispersed AOM containing smaller amounts of diatoms debris, suggests a lower productivity ( Fig. 3c).

\subsection{Aerobic vs. anaerobic degradation processes in Mejillones Bay}

Although geochemical and petrographic data suggest a similar origin for the agglomerated and dispersed amorphous AOM accumulating in marine sediments of Mejillones Bay, we hypothesize that their optical properties are related to differences in microbial breakdown to which the material is exposed during its transit through the water column (Lallier-Vergès et al., 1991; Lallier-Vergès et al., 1993; Boussafir and Lallier-Vergès, 1997; Meyers and LallierVergès, 1999). In Mejillones Bay, the water column is characterized by a stratified condition. Oceanographic data taken during a normal year (non-El Niño), shows that surface water has high dissolved oxygen contents, while subsurface waters are poorly ventilated (Fig. 6). This situation is intensified during spring and summer seasons, when biological productivity increases due to a more intense upwelling. This situation, would lead to organic matter being exposed to different oxygenation conditions during its transit to bottom sediments, and thus, different degradation mechanisms changing its original structure and composition. 


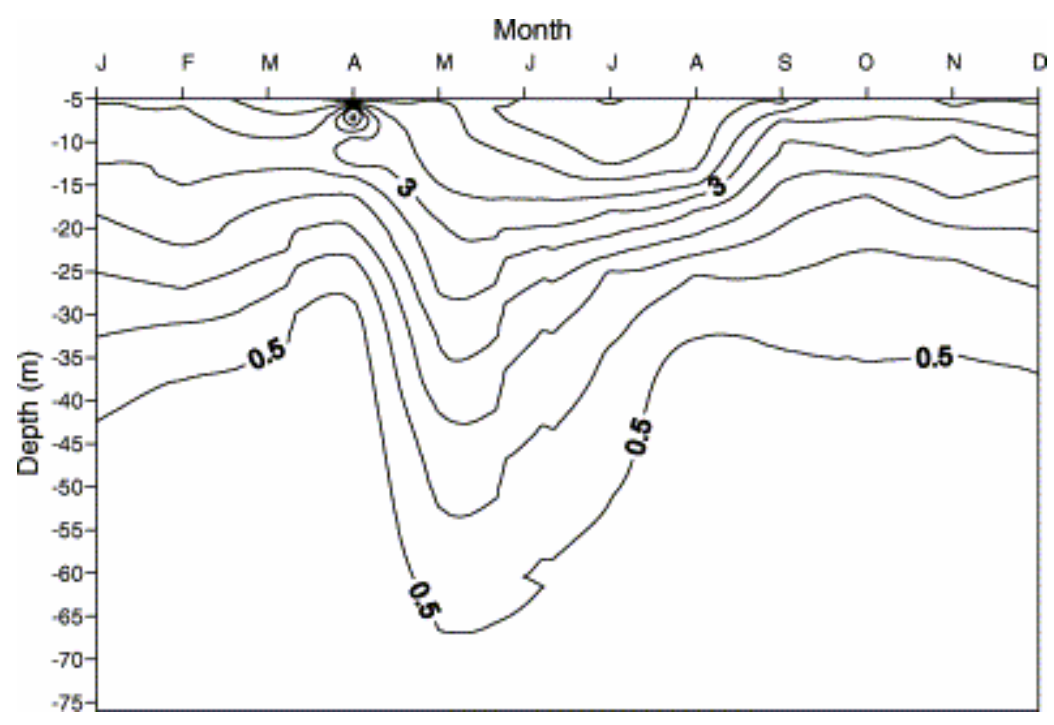

Fig. 6. Annual variation of dissolved oxygen in Mejillones Bay. Data correspond to 1995.

For example, differences in relative intensities of the bands observed in the FTIR spectra between organic fractions exhibiting different structures (Fig. 4) can be interpreted as variations in intensity of oxidation-reduction processes having affected the organic matter during its sedimentation and diagenesis ( Tribovillard et al., 1994). Oxidation of kerogens is marked by a decrease in aromatic and aliphatic $\mathrm{CH}$ band intensity and by an increase in $\mathrm{OH}$ and $\mathrm{C}=\mathrm{C}+\mathrm{C}=\mathrm{O}$ band intensity (Rochdi et al., 1991). The Oxidation Index was applied to compare the oxidation state of agglomerated and dispersed kerogen of Mejillones Bay, using the ratio between the surfaces of IR bands $\left[\left(1710 \mathrm{~cm}^{-1}+1610 \mathrm{~cm}^{-1}\right) / 2900 \mathrm{~cm}^{-1}\right]$ (Benalioulhadj and Trichet, 1990; Lallier-Vergès et al., 1993). The results showed that the agglomerated organic material had a higher oxidation index $(\approx 1.74)$ than the dispersed material $(\approx 1.45)$, indicating that the former was more oxidized than the latter. Differences in oxidative states are also suggested by the van Krevelen-type plot ( Fig. 5) which indicates the oxidation route between dispersed and agglomerated AOM ( Meyers and Lallier-Vergès, 1999). This plot shows that when hydrogen-rich organic matter is oxidized, its hydrogen content decreases. When combining petrographic and geochemical results ( Fig. 5), most of the samples with abundant agglomerated organic matter were observed to have low HI values, also indicative that this matter was more highly oxidized ( Meyers and Lallier-Vergès, 1999).

This evidence suggests that agglomerated matter shows signs of degradation in aerobic environment, while dispersed matter does not. A plausible explanation for these differences is that agglomerated AOM contains some organic material that survives the transit through oxygenated surface waters and reaches the anoxic bottom waters of the bay. In contrast, dispersed AOM represents a situation in which only organic material that is not (or less) affected by oxidative processes reaches the deoxygenated bottom waters, while reactive organic material is degraded in aerobic surface environment. This explanation is supported by the idea that marine amorphous organic matter is a combination of metabolizable and nonmetabolizable matter, which are affected in different ways by oxygen availability. Thus, it is proposed that the dispersed AOM from Mejillones Bay would represent metabolizable material, while agglomerated AOM would represent a combination of both metabolizable and non-metabolizable materials which provide evidence of breakdown in an aerobic environment. 
Normally, the TOC to TN $(\mathrm{C} / \mathrm{N})$ ratio can be used to characterize the type of organic matter, because different groups of organisms produce organic matter that contain different carbon and nitrogen contents (Libes, 1992). This ratio can be used to identify marine and terrestrial organic matter, based on a value of 10 as a separation between them ( Stein, 1991; Thunell et al., 1992). In the case of the sediment core from Mejillones Bay, mean $\mathrm{C} / \mathrm{N}$ ratio was 13 , that is slightly superior to the limit for marine organic matter ( Fig. 2). Is accepted that nitrogen, which is a constituent of proteins ( Brown et al., 1994), is rapidly remineralized after death of the organisms in surface water, and does not participate as such in kerogen formation ( Vandenbroucke, 1980; Durand and Monin, 1980; Verardo and Mcintyre, 1994). The profile of the $\mathrm{C} / \mathrm{N}$ ratio in $32 \mathrm{~B}$ core, correlates with others parameters, based on stratigraphic units. The fact that higher values of this ratio are present in unit $\mathrm{C}$, associated with dispersed AOM, is interpreted as evidence of loss of metabolizable organic matter (proteins in this case) before it reaches the sea floor. In contrast, the lower $\mathrm{C} / \mathrm{N}$ of unit $\mathrm{A}$ provides evidence of the presence of metabolizable organic matter in bottom sediments, associated to agglomerated AOM, is supported by a higher nitrogen content, that decreases the $\mathrm{C} / \mathrm{N}$ ratio.

It is accepted that the presence of framboidal pyrite in marine sediments is evidence of organic matter degradation by means of sulfate reduction due to the presence of a high content of metabolizable organic matter (Lallier-Vergès et al., 1993; Bertrand et al., 1993; LallierVergès et al., 1997). In the sediment core of Mejillones bay, the relationship between high abundance of pyrite and high content of agglomerated AOM ( Fig. 2), could be interpreted as a evidence of metabolizable material that reaches the sea floor. The relationship between metabolizable organic matter and sulfate reduction may be approached by means of calculation of the Sulfate Reduction Index (SRI), as defined by Bertrand and Lallier-Vergès (1993), Lallier-Vergès et al. (1993), and Boussafir et al. (1996). Sulfur content in sediment core of Mejillones is very low. This situation could limit the sulfate reduction mechanism, but the significant differences between stratigraphic units showed by one-way ANOVA analysis show that unit A, characterized by high agglomerated AOM and high sulfur content is significantly different from unit $\mathrm{C}$, which has dispersed AOM and low sulfur content. To highlight these differences, we coupled the microscopic investigations of organic matter to the geochemical bulk analysis by means of SRI and Agglomeration Index (AI). In this last case, we defined the AI as the agglomerated and dispersed ratio (brown AOM + black AOM/yellow AOM), which estimates the metabolizable organic matter that reached the sea floor. The summation of these indexes demonstrated a good separation between samples in which dispersed organic material predominated (lower values of SRI and agglomeration index) over those with more agglomerated organic matter (Fig. 7). This may represent the effect of the availability of metabolizable components of organic matter on sulfate reduction efficiency. 


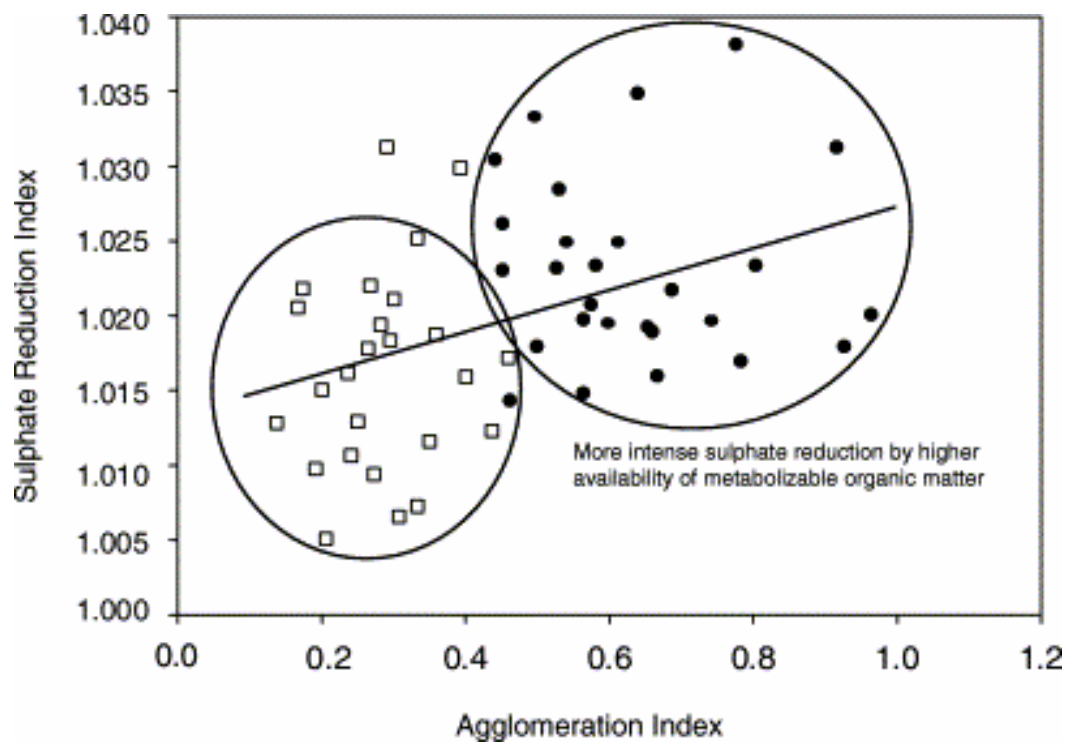

Fig. 7. Agglomeration Index vs. SRI, in 32B core. Filled circles correspond to agglomerated material, rich in metabolizable AOM. White squares correspond to dispersed material, with less metabolizable AOM.

To summarise, in Mejillones Bay marine organic matter produced in photic zone is exposed to different mechanisms of degradation during its transit across the water column. The combination of aerobic and anaerobic processes acting on organic matter formed by both metabolizable and non-metabolizable material are the key to correlate compositional and structural characteristics of bottom sediment with oceanographic and sedimentary situation prevailing in this bay, during the recent past.

\subsection{Interpretative model of sedimentation in Mejillones Bay}

The study carried out on core 32B allowed the identification of variations in geochemical and petrographic parameters, which are associated with different compositions of the total sediment and of its organic fraction. All these interpretations are now integrated into an interpretative model proposed to define the paleoceanographic characteristics of Mejillones Bay, based on the sedimentary record. This conceptual model is based on the increase in agglomerated vs. dispersed AOM, by means of a combination of mechanisms, which allows for an identification of two "Oceanographic Phases" (Fig. 8). In both cases, the basis of the model is biological productivity, which introduces two types of organic material into the system: metabolizable and non-metabolizable (non-degradable) organic matter (Boussafir and Lallier-Vergès, 1997). Depending on the intensity of the productivity, a series of mechanisms are generated and influence the behavior of both types of organic matter, in the water column and in sediments ( Bertrand et al., 1993; Bertrand and Lallier-Vergès, 1993; Lallier-Vergès et al., 1997; Vetö et al., 2000; Brüchert et al., 2000). This leads to the production of a structure and composition easily recognized within the sedimentary sequence in Mejillones Bay. 


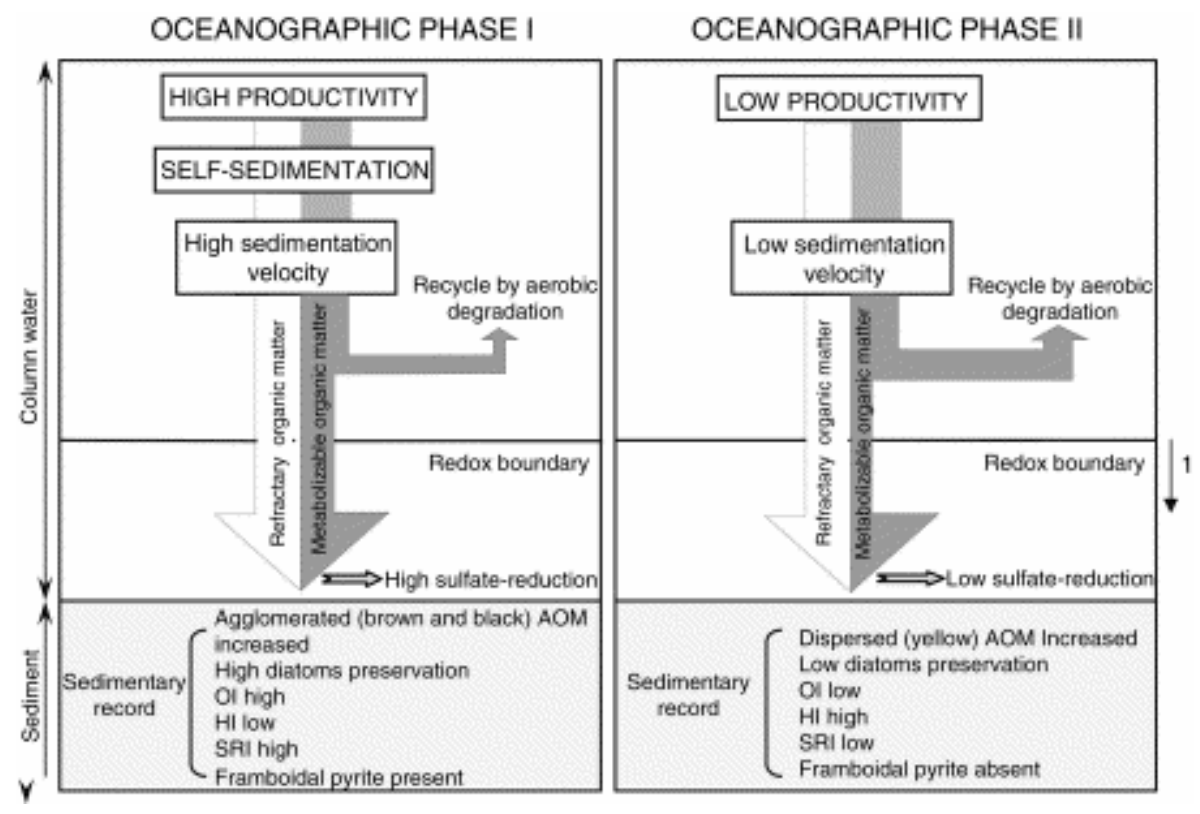

Fig. 8. Interpretative model for marine organic sedimentation proposed for Mejillones Bay. In this model, the sedimentary record is formed according to two different oceanographic phases. Number 1 represent a change in redox boundary, which could be associated with an El Niño event.

The Oceanographic Phase I (Fig. 8) is characterized by high primary productivity marked in the sediments by abundant Chaetoceros, typical of upwelling systems (Sauter and Sancetta, 1992; Bull and Kemp, 1995; Rodríguez and Escribano, 1996). The generation of a large quantity of phytoplankton biomass promotes the flocculation of particulate (biological and mineral) material, due to the production of mucilaginous compounds and polysaccharides, which agglutinate particles present in the water column ( Jacson, 1990; Lallier-Vergès et al., 1997). This mechanism, called "self sedimentation" has been studied by Grimm et al. (1997) in marine geological records, and is responsible for the increased efficiency of the exportation of metabolizable organic material from the water column to the bottom sediments ( LallierVergès et al., 1997). Thus it is assumed that the high productivity triggers the process of "self sedimentation" (flocculation), increasing the velocity of descent of material through the water column ( Wefer, 1989). The result is the presence, in the sediments, of agglomerated AOM formed by aggregates of non-metabolizable and metabolizable organic matter. This latter organic fraction, which shows evidence of the effects of oxidation during its transit through the oxic zone, explains the signs of oxidation observed in the geochemical parameters (high OI and oxidation index based on FTIR). Also, the large quantity of organic matter reaching the sea bottom promotes higher rates of sulfate reduction, recorded by the presence of framboidal pyrite, and by the high sulfate reduction index.

The Oceanographic Phase II (Fig. 8) shows the opposite situation. In this case the biological productivity decreases and the sediments are marked by the absence (or paucity) of Chaetoceros and others siliceous phytoplankton. Since this lower productivity does not promote the "self sedimentation" mechanism, no flocculent organic matter is present. The rate of sinking of organic matter markedly diminishes. These phenomena lead to an extensive recycling of degradable organic matter within the aerobic compartment of the water column and the predominant deposition of non-metabolizable organic mater (dispersed AOM). This explains the observed low oxygen index and high hydrogen index and the more hydrogenated composition of the organic matter. This low import of metabolizable material to the bottom sediments does not favor sulfate reduction and explains the absence of framboidal pyrite. 


\section{Conclusions}

The interpretative model presented suggests that, while the sedimentation of organic material in Mejillones Bay is principally controlled by productivity, the Oceanographic Phase I corresponds to "normal" conditions, with intense upwelling and high productivity, a situation that favors the deposition and preservation of metabolizable organic matter. Vargas, 1998 and Vargas, 2002, who carried out a study of thin laminae in this same sediment core demonstrated that the dark layers (as seen in radioscopy) contained a larger quantity of detrital material than the lighter laminae. The author interpreted the presence of abundant terrigenous particles as resulting from stronger (or more frequent) southerly winds. In the Mejillones area these winds are responsible for seasonal upwelling ( Rutllant, 1993; Marín and Olivares, 1999) in such a way that the increase in lithogenic particles may be related with the increase in productivity.

The interpretative model presented here also suggests that Oceanographic State II represents conditions of lower productivity during which the deposition of non-metabolizable organic material predominates. This situation seems to occur during periods of less intense upwelling and/or during episodes characterized by changes of the redox boundary position. Several authors (Escribano, 1998; Gonzalez et al., 1998 and Gonzalez et al., 2000) documented that the intrusion of tropical waters during strong El Niño events generates a strong oxygenation of the water column within the bay. The lowering of the oxycline, which separates the well aerated and the low aerated sectors, leads to the exposition of a large part of the water column, and eventually the bottom sediment, to a more oxygenated environment. Consequently, the organic material remains exposed to oxic conditions for a relatively longer time than during the Oceanographic State I. This longer exposure favors the recycling of the degradable organic components prior to their incorporation into the sediments.

We interpret that the sedimentary units recognized through radioscopic analyses and according to the geochemical and petrographic composition of the marine sediment depict combinations of two oceanographic states as proposed by the interpretative model in Fig. 8 . Accordingly, three different oceanographic scenarios would have prevailed in Mejillones Bay, during the time covered by the sedimentation of the 32B core; Unit A, which corresponded to a predominant oceanographic state II; unit B, which was formed by an abrupt alternation of the two Oceanographic States I and II; and unit C, which was characterized by more frequent oceanographic state I.

\section{Acknowledgements}

The authors thank Sandrine Caquineau, Jacques Bertaux (†26 september 2002), Jean-Robert Disnar, Patricia Martins and Marielle Hatton for their collaboration during the sample analyses. The core analyzed was recovered during the sampling program of FONDECYT Project 2960074. The first author benefited from an IRD support while he carried out research activities at the Universidad Federal Fluminense (Brazil) and the ISTO, Universié d' Orléans (France). Geochemical analyses were carried out at the Department of Geochemistry at the Universidade Federal Fluminense and in the "Institut des Sciences de la Terre d'Orléans France". The research was supported by the cooperative project PALEOBAME (Univ. de Antofagasta-IRD) and the program PALEOTROPIQUE (UR 055) of IRD. We also thank two anonymous reviewers for their comments and for significantly improving the manuscript. 


\section{References}

Bertrand, P., Lallier-Vergès, E. and Boussafir, M., 1993. Enhancement of accumulation and anoxic degradation of organic matter controlled by cyclic productivity, a model. Organic Geochemistry 22 3-5, pp. 511-520.

Bertrand, P. and Lallier-Vergès, E., 1993. Past sedimentary organic matter accumulation and degradation controlled by productivity. Nature 364, pp. 786-788.

Bertrand, P., Pedersen, T., Schneider, Shimmield, G., Lallier-Vergès, E., Disnar, J.R., Massias, Villanueva, Tribovillard, N.P., Huc Y., Giraud, P.C., Vennec-Perret M.N. 2003. Organic-rich sediments in ventilated deep-sea environments, climate, sea-level and trophic changes. Journal of Geophysical Research 108 (C2):3045

Benalioulhadj, S. and Trichet, J., 1990. Comparative study by infrared spectroscopy of the organic matter of phosphate-rich (Oulad Abdoun basin) and black shale (Timahdit basin) series (Morocco). Organic Geochemistry 16, pp. 649-660.

Boussafir, M. and Lallier-Vergès, E., 1997. Accumulation of organic matter in the Kimmeridge Clay Formation (KCF), an update fossilisation model for marine petroleum source-rocks. Marine and Petroleum Geology 14 1, pp. 75-83.

Brown, J., Colling, A., Park, D., Phillips, J., Rothery, D. and Wright, J., 1994. Ocean chemistry and deep-sea sediments. In: The Open University/Pergamon, Elsevier, Oxford, p. 133.

Brüchert, V., Pérez, M. and Lange, C., 2000. Coupled primary production, benthic foraminiferal asamblage, and sulfur diagenesis in organic-rich sediments of the Benguela upwelling system. Marine Geology 163, pp. 27-40.

Bull, D., Kemp, A., 1995. Composition and origins of laminae in Late Quaternary and Holocene sediments from the santa Barbara Bassin. In: Kenett, J., Baldauf, J., Lyle, M. (Eds.), Proceedings of the Ocean drilling Program. Scientific Results, 146 (2), 77-88

Calvert, S., Bustin, R. and Pedersen, T., 1992. Lack of evidence for enhanced preservation of sedimentary organic matter in the oxygen minimum of the Gulf of California. Geology 20, pp. 757-760.

Calvert, S., Bustin, R. and Ingall, E., 1996. Influence of water column anoxia and sediment supply on the burial and preservation of organic carbon in marine shales. Geochimica et Cosmochimica Acta 60 9, pp. 1577-1593.

Cowie, G., Calvert, S., Pedersen, T., Schulz, H. and von Rad, U., 1999. Organic content and preservational controls in surficial shelf and slope sediments from the Arabian Sea (Pakistan margin). Marine Geology 161, pp. 23-38.

Didyk, B., Simoneit, B., Brassell, S. and Eglinton, G., 1978. Organic geochemical indicators of paleoenvironmental conditions of sedimentation. Nature 272 5660, pp. 216-222. 
Duan, Y., 2000. Organic geochemistry of recent marine sediments from the Nansha Sea, China. Organic Geochemistry 31, pp. 159-167.

Durand, B., Nicaise, G., 1980. Procedures for kerogen isolation. In: Durand, B. (Ed.), Kerogen, insoluble organic matter from sedimentary rocks, Technip, Paris, pp. 35-54

Durand, B., Monin, J., 1980. Elemental analysis of kerogen (C,H,O,N,S,Fe). In: Durand, B. (Ed.), Technip, Paris, pp. 113-142

Durand, B., 1980. Sedimentary organic matter and kerogen. Definition and quantitative importance of kerogen. In: Durand, B. (Ed.), Kerogen, insoluble organic matter from sedimentary rocks, Technip, Paris, pp. 13-34

Escribano, R., 1998. Population dynamics of Calanus chilensis in the Chilean Eastern Boundary Humboldt Current. Fisheries Oceanography 7 3/4, pp. 245-251.

Escribano, R. and Hidalgo, P., 2000. Spatial distribution of copepods in the north of the Humboldt Current region off Chile during coastal upwelling. Journal of Marine Biology ASS. UK 80, pp. 1-8.

Ganeshram, R.S., Calvert, S.E., Pederson, Th.F. and Cowie, G.L., 1999. Factors controlling the burial of organic matter in laminated and bioturbeted sediments of NW Mexico, Implications for hydrocarbon preservation. Geochimica et Cosmochimica Acta 63 11/12, pp. $1723-1724$.

Gonzalez, H., Daneri, G., Figueroa, D., Iriarte, J., Lefevre, N., Pizarro, G., Quiñines, R., Sobarzo, M., Troncoso, A., 1998. Producción Primaria y su destino en la trama trófica pelágica y océano profundo e intercambio océano-atmósfera de $\mathrm{CO} 2$ en la zona norte de la corriente de Humboldt $\left(23^{\circ} \mathrm{S}\right)$, posibles efectos del evento El Niño, 1997-98 en Chile. Revista Chilena de Historia Natural 71, 429-458

Gonzalez, H., Ortiz, V. and Sobarzo, M., 2000. The role of faecal material in the particulate organic carbon fllux in the northern Humboldt Current, Chile $\left(23^{\circ} \mathrm{S}\right)$, befote an during the 1997-1998 El Niño. Journal of Plankton Research 22 3, pp. 499-529.

Grimm, K., Lange, C. and Gill, A., 1997. Self-sedimentation of phytoplankton blooms in the geologic record. Sedimentary Geology 110, pp. 151-161.

Hedges, J. and Keil, R., 1995. Sedimentary organic matter preservation, an assessment and speculative synthesys. Marine Chemistry 49, pp. 81-115

Hollander, D., Mckenzie, J. and Ten Haven, H., 1992. A 200 year sedimentary record of progressive eutrophication in lake Greifen (Switzerlan), Implications for the origin of organiccarbon-rich sediments. Geology 20, pp. 825-828.

Hulthe, G., Hulth, S. and Hall, P., 1998. Effect of oxygen on degradation rate of refractory and labile organic matter in continental margin sediments. Geochimica et Cosmochimica Acta 62 8, pp. 1319-1328. 
Hulth, S., Aller, R. and Gilbert, F., 1999. Coupled anoxic nitrification/manganese reduction in marine sediments. Geochimica et Cosmochimica Acta 63 1, pp. 49-66.

Ingall, E. and Jahnke, R., 1994. Evidence for enhanced phosphorus regeneration from marine sediments overlain by oxygen depleted waters. Geochimica et Cosmochimica Acta 58 11, pp. 2571-2575.

Jacson, G., 1990. A model of the formation of marine algal flocs by physical coagulation processes. Deep-Sea Research 37 8, pp. 1197-1211.

Jones, B. and Manning, D., 1994. Comparison of geochemical indices used for the interpretation of paleoredox conditions in ancient mudstones. Chemical Geology 111, pp. 111-129.

Lafargue, E., Marquis, F. and Pillot, D., 1998. Rock-Eval 6 applications in hydrocarbon exploration, production, and soil contamination studies. Revue de L'Institut Francais du Pètrole 53 4, pp. 421-437.

Lallier-Vergès, E., Bertrand, P., Desprairies, A., Berner, U., 1991. Geochemical and optical investigations on degradation processes affecting organic matter in Celebes Basin sediments. In: Silver, E., Rangin, C., van Breymann, M. (Eds.), Proceedings of the Ocean Drilling Program, Scientific Results, ODP, 124, 239-247

Lallier-Vergès, E., Hayes, J., Boussafir, M., Zaback, D., Tribovillard, N., Connan, J. and Bertrand, P., 1993. Productivity-induced sulphur enrichment of hydrocarbon-rich sediments from the Kimmeridge Clay Formation. Chemical Geology 134 4, pp. 177-188.

Lallier-Vergès, E., Hayes, J., Boussafir, M., Tribovillard, N.P., Zaback, D., Bertrand, P. and Connan, J., 1997. Productivity-induced Sulfur enrichment of organic-rich sediments. Chemical Geology 134/4, pp. 277-288.

Lallier-Vergès, E., Martinez, P., Bertrand, P., Rabouille, C., Relexans, J.C. and Keravis, D., 1998. Sedimentation, reworking and preservation of organic matter in surficial sediments of the N-W african upwelling system. Mineralogical Magazine 62A, pp. 846-847.

Libes, S., 1992. An Introduction to Marine Biogeochemistry., John Wiley \& Sons, Inc., New York 289 pp. .

Lükge, A., Boussafir, M., Lallier-Vergès, E. and Littke, R., 1999. Comparative study of organic matter preservation in inmature sediments along the continental margins of Peru and Oman. Part I, Results of petrographical and bulk geochemical data. Organic Geochemistry 24 4, pp. 437-451.

Marín, V., Rodríguez, L., Vallejo, L., Fuenteseca, J. and Oyarce, E., 1993. Efectos de la surgencia costera sobre la productividad primaria primaveral de la Bahía Mejillones del Sur (Antofagasta, Chile). Revista Chilena de Historia Natural 66, pp. 47-491.

Marín, V. and Olivares, G., 1999. Estacionalidad de la productividad primaria en bahía Mejillones del Sur (Chile), una aproximación proceso-funcional. Revista Chilena de Historia Natural 72, pp. 629-641. 
Martinez, P., Bertrand, P., Calvert, S.E., Shimmield, G.B., Cochrane, K., Jorissen, F., Foster, J. and Dignan, M., 1999. Upwelling intensity and ocean productivity changes off Cape Blanc (northwest Africa) during the last 70,000 years, geochemical and micropaleontological evidence. Marine Geology 158, pp. 57-74.

Martinez, P., Bertrand, P., Calvert, S.E., Pedersen, T.F., Shimmield, G.B., Lallier-Vergès, E., Fontugne, M., 2000. Spatial variations in nutrient utilization, production and diagenesis in the sediments of a coastal upwelling regime (NW Africa), Implications for the paleoceanographic record. Journal of Marine Research 58 (5) (in press)

Meyers, P. and Lallier-Vergès, E., 1999. Lacustrine sedimentary organic matter records of Late Quaternary paleoclimates. Journal of Paleolimnology 21, pp. 345-372.

Müller, P. and Suess, E., 1979. Productivity, sedimentation rate, and sedimentary organic matter in the ocean - I. Organic carbon preservation. Deep-Sea Research 26A, pp. 13471362.

Murria, J. and Kuivila, K., 1990. Organic matter diagenesis in the northeast Pacific, transition from aerobic red clay to suboxic hemipelagic sediments. Deep-Sea Research 37 1, pp. 59-80.

Ortlieb, L., Zúñiga, O., Follegati, R., Escribano, R., Kong, I., Rodríguez, L., Mourguiart, Ph., Valdes, J., Iratchet, P., 1994. Paleoceanografía de la Bahía de Mejillones del Sur (Antofagasta, Chile), Resultados preliminares para el último milenio. Estudios Oceanológicos $13,45-55$

Ortlieb, L., Escribano, R., Follegati, R., Zuñiga, O., Kong, I., Rodriguez, L., Valdes, J., Iratchet, P. and Guzmán, N., 2000. Ocean-climatic changes during the last 2,000 years in a hypoxic marine environment of Northern Chile $\left(23^{\circ} \mathrm{S}\right)$. Revista Chilena de Historia Natural 73, pp. 221-242.

Pedersen, T. and Calvert, S., 1990. Anoxia vs. productivity, What controls the formation of organic-carbon-rich sediments and sedimentary rocks?. American Association of Petroleum Geologists Bulletin 74, pp. 454-466.

Pichon, J., 1985. Les diatomées traceurs de l'évolution climatique et hydrologique de lOcéean Austral au cours du dernier cycle climatique. These de doctorat de l'Université de Bordeaoux I, $219 \mathrm{pp}$

Ransom, B., Kim, D., Kastner, M. and Wainwright, S., 1998. Organic matter preservation on continental slope,Importance of mineralogy and surface area. Geochimica et Cosmochimica Acta 62 8, pp. 1329-1345.

Reimers, C., 1989. Control of bemthic fluxes by particulate supply. In: Berger, W.H., et al., (eds.), Productivity of the ocean, past and present. Life Sciences Research Report, vol. 44, Wiley, pp. 217-234

Rodríguez, L., Escribano, R., 1996. Bahía Antofagasta y Bahía Mejillones del Sur, observaciones de la temperatura, penetración de la luz, biomasa y composición fitoplanctónica. Estudios Oceanológicos, 15, 75-85 
Rochdi, A., Landais, P. and Burneau, A., 1991. Analysis of coal by transmission FTIR microspectroscopy, methodological aspect. Bull. Soc. Géol. Fr. 162, pp. 155-162.

Rutllant, J., 1993. Coastal lows and associated southerly wind events in northern-central Chile. In: Preprints 4th International Conference on Southern Hemisphere Meteorology and Oceanography, American Meteorology Society, Boston, pp. 268-269

Sauter, L. and Sancetta, C., 1992. Seasonal association of phytoplankton and planktic foraminifera in an upwelling region and their contribution to the seafloor. Marine Micropaleontology 18, pp. 263-278.

Schulte, S., Mangelsdorf, K. and Rullkotter, J., 2000. Organic matter preservation on the Pakistan continental margin as revealed by biomarkers geochemistry. Organic Geochemistry 31, pp. 1005-1022.

Sifeddine, A., Bertrand, Ph., Lallier-Vergès and Patience, A., 1996. The relationships between lacustrine organic sedimentation and paleoclimatic variations, Lac du Bouchet, Massif Central, France. Q. Sci. Rev. 15, pp. 203-211.

Sifeddine, A., Bertrand, Ph., 1994. Essai d'analyse quantitative des palynofacies par traitement d'image, application sur un exemple de sedimentation lacustre _Le Lac du Bouchet (Massif Central, France). Bul. Centres Rech. Explor. Prod. Elf-Aquitaine, 18, 101-106

Stein, R., 1991. Accumulation of organic carbon in marine sediments. Results from the Deep Sea Drilling Project/Ocean Drilling Program (DSDP/ODP). In, Bhattachardji, S. et al. (Eds.), Lecture Notes in Earth Sciences, vol. 44, 217 pp

Thamdrup, B. and Canfield, D., 1996. Pathways of carbon oxidation in continental margin sediments off central Chile. Limnology and Oceanography 41 8, pp. 1629-1650.

Thomas, A., Blanco, J., Carr, M., Strub, P. and Osses, J., 2001. Satellite-measured chlorophyll and temperature variability off northern Chile during the 1996-1998 La Nina and El Nino. Journal of Geophysical Research 106 C1, pp. 899-915.

Thunell, R., Oingmin, M., Calvert, S. and Pedersen, F., 1992. Glacial-Holocene biogenic sedimentation patterns in the south China Sea, Productivity variations and surface water $\mathrm{pCO}_{2}$. Paleoceanography 7 2, pp. 143-162.

Tissot, B. and Welte, D., 1984. Petroleum Formation and Occurrence. (second ed.), Springer Verlag, Berlin 699 pp. .

Tribovillard, N., Desprairies, A., Lallier-Vergès, E., Bertrand, P., Moureau, N., Ramdani, A. and Ramanampisoa, L., 1994. Geochemical study of organic-matter rich cycles from the Kimmeridge Clay Formation of Yorkshire (UK), productivity versus anoxia. Palaeogeography, Palaeoeclimatology and Palaeoecology 108, pp. 165-181.

Valdés, J., 1998. Evolución oceanográfica reciente de la Bahía Mejillones del Sur $\left(23^{\circ} \mathrm{S}\right)$. Evidencia geoquímica en sedimentos marinos. Tesis Doctoral, Centro EULA-Chile Universidad de Concepción, $114 \mathrm{p}$ 
Valdés, J., López, L., Lomónaco, S. and Ortlieb, L., 2000. Condiciones paleoambientales de sedimentación y preservación de materia orgánica en Bahía Mejillones del Sur $\left(23^{\circ} \mathrm{S}\right)$, Chile. Biología Marina y Oceanografía. Rev. Biol. Mar. y Ocean. 35 2, pp. 169-180.

Valdés, J. and Ortlieb, L., 2001. Paleoxigenación subsuperficial de la columna de agua en la bahía Mejillones del Sur $\left(23^{\circ} \mathrm{S}\right)$, Indicadores geoquímicos en testigos de sedimento marino. Investigaciones Marinas 29 1, pp. 25-35.

Valdés, J., Ortlieb, L., Sifeddine, A., 2003. Variaciones del sistema de surgencia de Punta Angamos $\left(23^{\circ} \mathrm{S}\right)$ y la Zona de Mínimo Oxígeno durante el pasado reciente. Una aproximación desde el registro sedimentario de la bahía Mejillones del Sur. Revista Chilena de Historia Natural. En prensa

Vandenbroucke, M., 1980. Structure of kerogen as seen by investigations on soluble extracts. In: Durand, B. (Ed.), Technip, Paris, pp. 418-443

Vargas, G., 1998. Approches méthodologiques en paléo-océanographie réalisées à partir de carottes de la Baie de Mejilles, Chile $\left(23^{\circ} \mathrm{S}\right)$. Diplôme d'Etudes Approfondies, Iniversité Bordeaux I, $32 \mathrm{pp}$

Vargas, G., 2002. Interactions ocean-atmosphère au cours des derniers siècles sur la côte du Désert d' Atacama, analyse multi-proxies des sédiments laminés de la Baie de Mejillones $\left(23^{\circ} \mathrm{S}\right)$. Tesis Doctoral, Universidad de Bordeaux I, Francia, $270 \mathrm{pp}$

Verardo, D., Mcintyre, A., 1994. Production and destruction, control of biogenous sedimentation in the tropical Atlantic 0-300,000 years B.P. Paleoceanography $9(1), 63-86$

Vetö, I., Hetenyi, M., Hamor-Vido, M., Hufnagel, H. and Haas, J., 2000. Anaerobic degradation of organic matter controlled by productivity variation in a restricted Late Triassic basin. Organic Geochemistry 31, pp. 439-452.

Wefer, G., 1989. Particle flux in the ocean, effects of episodic production. In: Berger, W.H., Smetacek, V.S., Wefer, G. (Ed.), Report of the Dahlem Workshop on productivity of the ocean, present and past, Berlin 1988, Wiley, Chichester, pp. 139-154

Zúñiga, O., 1974. Cálculo preliminar de la biomasa bentónica de la bahía de Mejillones. Apuntes Oceanológicos, 6, 1-10

Zúñiga, O., Baeza, H. and Castro, R., 1983. Análisis de la macrofauna bentónica del sublitoral de la bahía de Mejillones del Sur. Estudios Oceanológicos 3, pp. 41-62. 